\title{
Physicians' preference towards the non-evidence based hydroxychloroquine treatment for COVID-19: the pandemic effect
}

\section{Luis Claudio Correia' ${ }^{1}$ (]) João Ricardo Pinto Lopes ${ }^{2}$ (1) Flávia Barreto Garcez ${ }^{3}$ (1) Edmond Le Campion ${ }^{4}$ (1) Guilherme Barcellos ${ }^{5}$ (1) José Augusto Barreto-Filho ${ }^{6}$ (1)}

${ }^{1}$ Centre for Evidence-based Medicine, Escola Bahiana de Medicina e Saúde Pública (Salvador); Choosing Wisely Brazil. Bahia, Brazil. luisclcorreia@gmail.com ${ }^{2}$ Corresponding author. Centre for Evidence-based Medicine, Escola Bahiana de Medicina e Saúde Pública (Salvador). Bahia, Brazil. jrpintolopes@yahoo.com.br 3Universidade de São Paulo (São Paulo). São Paulo, Brazil. flavia.garcez@usp.br ${ }^{4}$ Choosing Wisely Brazil; Universidade Federal de Goiás (Goiânia). Goiás, Brazil. campion@usp.br ${ }^{5}$ Choosing Wisely Brazil; Hospital de Clínicas de Porto Alegre (Porto Alegre). Rio Grande do Sul, Brazil. gbbarcellos@gmail.com 6Universidade Federal de Sergipe (São Cristovão); Rede D'Or São Luiz - Hospital São Lucas (Aracaju). Sergipe, Brazil. joseaugusto.se@gmail.com
ABSTRACT | OBJECTIVE: To evaluate whether there is a "pandemic effect" promoting irrational medical reasoning. METHODS: Crosssectional study. State medical councils were asked to send all registered physicians two sequential email invitations to complete a Google Form questionnaire. Between April 15 and May 3, 2020, 370 doctors answered our questionnaire with questions about the prescription of hydroxychloroquine for COVID-19 and vitamin $C$ for sepsis. The questionnaire had a five-point Likert scale (higher number, higher support) on the degree of propensity to prescribe the medication and a binary question (yes or no) to express the doctor's final decision to prescribe. These two questions, in the same order, were asked for scenarios of mild, moderate and severe cases. RESULTS: The propensity to prescribe hydroxychloroquine for COVID-19 increased with the severity of the clinical presentation: for mild cases, 37\% (95\% Cl 32\%-42\%) of the physicians chose "yes", increasing to $68 \%$ (95\% Cl 63\%-72\%) and $89 \%$ (95\% Cl 85\%-92\%) for moderate or severe cases, respectively (Cochran's $\mathrm{Q}$ test: $\mathrm{P}<0.001)$. The medians and interquartile ranges of the Likert scales for hydroxychloroquine were 2 (1-4), 4 (2-4), 4 (4-5) in mild, moderate and severe cases of COVID-19 (Friedman test: $\mathrm{P}<0.001)$. CONCLUSIONS: The propensity of the Brazilian physician to prescribe hydroxychloroquine for COVID-19 is high and, according to the severity of the disease, ranged from 37 to $89 \%$. On the contrary, the propensity to prescribe vitamin C for sepsis, a non-pandemic situation, was lower and not associated with clinical severity. Our data suggest a "pandemic effect" promoting irrationality in medical reasoning.

Keywords:COVID-19. Evidence-Based Medicine. Hydroxychloroquine. 


\section{Introduction}

Hydroxychloroquine has been widely prescribed as a treatment for COVID-19 patients since mid-March¹. Prescription enthusiasm was triggered by a high risk of bias French study ${ }^{2}$, with an impressive Altimetric of 7.748 as of May 1st, which was more ideologically than scientifically endorsed.

Hydroxychloroquine has potential unintended consequences ${ }^{3}$ and no proof of efficacy according to evidence-based principles ${ }^{4}$. It is not known whether physicians feel compelled to prescribe hydroxychloroquine because of the collective commotion or if prescription is mediated by their own preferences towards the treatment. We hypothesized that there is a "pandemic effect" promoting irrational medical reasoning.
Six state medical councils were asked to send all registered physicians two sequential e-mail invitations to fill a Google Form questionnaire. The Brazilian National Ethics Research Committee approved the protocol (CAAE 31015520.6.0000.0048).

The questionnaire had a header stating: "Hydroxychloroquine has been proposed as a treatment for COVID-19 but there is no scientific proof of efficacy so far". Then, it was followed by a five-point Likert Scale (higher number, higher support) on the degree of propensity to prescribe the drug and a binary question (yes or no) to express physician final decision to prescribe. These two questions, in the same order, were performed for scenarios of mild, moderate and severe cases.

As a control question, we used the same questions for vitamin C in sepsis, a non-evidence based treatment, but not related to SARS-Cov-2 pandemic.

The primary endpoint was predefined as the binary response. We planned a sample size of 385 individuals to provide a precision of $\pm 5 \%$ for the binary frequency of positive response regarding prescription, assuming a prevalence of $50 \%(95 \% \mathrm{Cl})$. 


\section{Questionário sobre o uso de Cloroquina/Hidroxicloroquina em Pacientes com COVID 19 e uso de Vitamina $\mathrm{C}$ em Pacientes com Sepse.}

Esse estudo trata-se de uma pesquisa com perguntas simples e diretas sobre o uso de dois fármacos (hidroxicloroquina e vitamina $\mathrm{C}$ ) em duas doenças potencialmente graves (COVID 19 e Sepse), em situações clínicas distintas. Se você concorda em participar dessa pesquisa, basta responder ao questionário, que terá um tempo estimado de respostas de 3 minutos. Os dados de sua identificação serão absolutamente sigilosos. Esse estudo foi aprovado pelo CEP do Hospital São Rafael. Pesquisadores Responsáveis: Luís C. L. Correia, João Ricardo Pinto Lopes, Flávia Barreto Garcez, Edmond Le Campion, Guilherme Barcellos, José Augusto Barreto-Filho.

Sua aceitação em participar da pesquisa será confirmada e tem o mesmo valor do Termo de Consentimento Livre e Esclarecido a partir do momento automático das suas respostas do e-mail.

Informações cadastrais dos Médicos:

Sexo: Masculino( ) Feminino ( )

Idade: anos

Ano de formatura:

Estado:

Especialidade Médica (favor escolher apenas uma):

- Especialidade cirúrgica ( )

- Medicina interna geral ( )

- Especialidade clínica ( )

- Medicina intensiva ( )

- Outra

Exerce alguma atividade de ensino:

- Sim ( ) Professor universitário（） Preceptoria ( )

- Não( )

Pós-graduação:

- Sim ( ) Mestrado ( ) Doutorado ( )

- Não（） 
PERGUNTAS:

1) Considerando que não há comprovação científica sobre o benefício da hidroxicloroquina para paciente com COVID-19, porém esta pode ser uma doença grave, qual o seu grau de concondância ao ato de prescrever essa medicação?

a) Em pacientes em quadro clínico leve

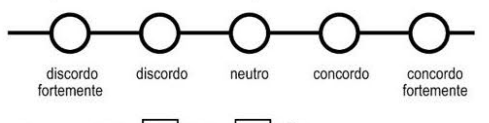

Prescreveria? $\square$ SIM $\square$ NÃO

b) Em paciente em quadro clínico moderado

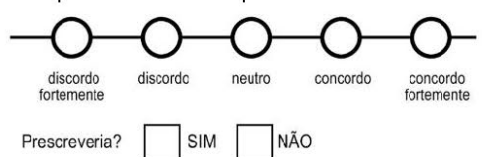

c) Em pacientes em quadro clinico grave

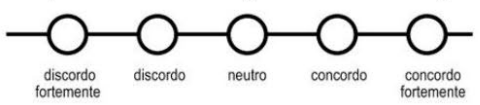

Prescreveria? $\square \operatorname{SIM} \square$ NĀO

2) Considerando que não há comprovação científica sobre o benefício da vitamina $C$ para pacientes com sepse bacteriana, porém esta pode ser uma doença grave, qual o seu grau de concondância ao ato de prescrever essa medicação?

a) Em pacientes em quadro clínico leve

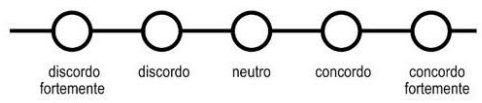

Prescreveria? $\square \operatorname{siM} \square$ Não

b) Em paciente em quadro clínico moderado

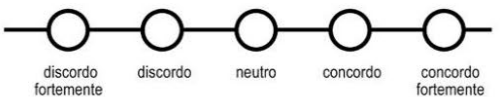

Prescreveria? $\square$ SIM $\square$ NÃO

c) Em pacientes em quadro clinico grave

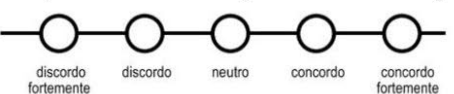

Prescreveria? $\square$ SIM $\square$ NÃO 
Four of the six invited medical councils did not feel comfortable approaching the issue in the midst of the pandemic. The two councils of Alagoas and Goias states agreed to send the questionnaire to their physicians, comprising a total of 21.962 invitations. Between April 15 and May 3, 370 physicians responded, age $42 \pm 11 \mathrm{yrs,} 61 \%$ males, $37 \%$ surgeons.

The propensity to prescribe hydroxychloroquine for COVID-19 increased with severity of clinical presentation: for mild cases, 37\% (95\%Cl 32\%-42\%) of physicians chose "yes", raising to 68\% (95\%Cl 63\%-72\%) and 89\% (95\%Cl 85\%$92 \%)$ for moderate or severe cases, respectively (Cochran's ' $Q$ ' test: $P<0.001$ ). Medians and interquartile ranges of Likert scales for hydroxychloroquine were $2(1-4), 4(2-4), 4$ (4-5) in mild, moderate and severe COVID-19 cases (Friedman's test: $\mathrm{P}<0.001$ ).

Compared with vitamin $C$ for sepsis, no difference was observed in propensity to prescribe for mild cases (37\% vs. $33 \%$; McNemar's test: $P=0.21)$, but in moderate $(68 \%$ vs. $39 \%$; $P$ < 0.001$)$ and severe cases $(89 \%$ vs. $43 \% ; P<$ $0.001)$ physicians' preference was higher for hydroxychloroquine. Regarding Likert scale, hydroxychloroquine and vitamin C were different within all three groups of severity - Table 1.

Table 1. Prescription Propensity in a Likert Scale and Binary Response

\begin{tabular}{|c|c|c|c|}
\hline Clinical status & $\begin{array}{c}\text { Hydroxychloroquine } \\
\text { COVID } 19\end{array}$ & $\begin{array}{c}\text { Vitamin C } \\
\text { Sepsis }\end{array}$ & P Value \\
\hline Mild Clinical Cases & & & $0.003^{\star}$ \\
\hline Strongly disagree & $100(28 \%)$ & $113(30 \%)$ & \\
\hline Disagree & $92(25 \%)$ & $95(26 \%)$ & \\
\hline Neutral & $56(15 \%)$ & $80(22 \%)$ & \\
\hline Agree & $83(23 \%)$ & $54(15 \%)$ & \\
\hline Strongly agree & $34(9,3 \%)$ & $27(7,3 \%)$ & \\
\hline Would you prescribe? Yes & $135(37 \%)$ & $121(33 \%)$ & 0.21 \\
\hline Moderate Clinical Cases & & & $<0.001^{k \star}$ \\
\hline Strongly disagree & $36(9,9 \%)$ & $95(26 \%)$ & \\
\hline Disagree & $55(15 \%)$ & $94(25 \%)$ & \\
\hline Neutral & $61(17 \%)$ & $84(23 \%)$ & \\
\hline Agree & $142(39 \%)$ & $58(16 \%)$ & \\
\hline Strongly agree & $69(19 \%)$ & $38(10 \%)$ & \\
\hline Would you prescribe? Yes & $246(68 \%)$ & $141(39 \%)$ & $<0.001^{* *}$ \\
\hline Severe Clinical Cases & & & $<0.001^{* *}$ \\
\hline Strongly disagree & $9(2,5 \%)$ & $82(22 \%)$ & \\
\hline Disagree & $18(4,9 \%)$ & $77(21 \%)$ & \\
\hline Neutral & $50(14 \%)$ & $102(28 \%)$ & \\
\hline Agree & $153(42 \%)$ & $64(17 \%)$ & \\
\hline Strongly agree & $134(37 \%)$ & $45(12 \%)$ & \\
\hline Would you prescribe? Yes & $322(89 \%)$ & $157(43 \%)$ & $<0.001^{* *}$ \\
\hline
\end{tabular}

aPaired comparison of Likert Scale and binary response between hydroxychloroquine and vitamin $C$ groups analyzed by Friedman's test and McNemar's test, respectively.

Boldface indicates statistical significance $\left({ }^{*} p<0.01, * * p<0.001\right)$.

The only variable associated with hydroxychloroquine propensity was years of professional experience (prescriptors versus non-prescriptors: $19 \pm 11$ and $14 \pm 11$; student's $t$ test: $P<0.001$ ). Gender, academic activity and post-doctoral titles were not related to the outcome. 


\section{Discussion}

Brazilian physician's propensity to prescribe hydroxychloroquine for COVID-19 is high and, according to disease severity, varied from 37 to $89 \%$. On the contrary, propensity to prescribe vitamin C for sepsis, a non-pandemic situation, was lower and not associated with clinical severity. Our data suggests a "pandemic effect" promoting irrationality on medical reasoning.

The key limitation of the present study includes a sample that was not representative of the entire population of physicians in the country, which might impact generalizability of our findings.

In times where rational clinical decision-making is of utmost importance, our preliminary data raises concern regarding the role of collective emotional stress guiding the prescription of non-evidence based therapies.

\section{Author contributions}

Correia LC, Barreto Filho JA were responsible for the literature review, conception and planning, study design and methods, data analysis and conclusion and writing of the manuscript. Lopes JR, Garcez FB, Le Campion E, Barcellos $G$ were responsible for the literature review, study design and methods, data analysis and discussion of the results

\section{Competing interests}

No financial, legal or political competing interests with third parties (government, commercial, private foundation, etc.) were disclosed for any aspect of the submitted work (including but not limited to grants, data monitoring board, study design, manuscript preparation, statistical analysis, etc.).

\section{References}

1. Pastick KA, Okafor EC, Wang F, Lofgren SM, Skipper CP, Nicol MR et al. Review: Hydroxychloroquine and chloroquine for treatment of SARS-CoV-2 (COVID-19). Open Forum Infect Dis. 2020;7(4):130. doi: 10.1093/ofid/ofaa130

2. Gautret P, Lagier JC, Parola P, Hoang VT, Meddeb L, Mailhe $M$ et al. Hydroxychloroquine and azithromycin as a treatment of COVID-19: results of an open-label non-randomized clinical trial. Int J Antimicrob Agents. 2020:105949. doi: 10.1016/j. ijantimicag.2020.105949

3. Kapoor A, Pandurangi U, Arora V, Gupta A, Jaswal A, Nabar A et al.. Cardiovascular risks of hydroxychloroquine in treatment and prophylaxis of COVID-19 patients: A scientific statement from the Indian Heart Rhythm Society. Indian Pacing Electrophysiol J. 2020;20(3):117-120. doi: 10.1016/j.ipej.2020.04.003

4. Chowdhury MS, Rathod J, Gernsheimer J. A rapid systematic review of clinical trials utilizing chloroquine and hydroxychloroquine as a treatment for COVID-19. Acad Emerg Med. 2020;27(6):493-504. doi: 10.1111/acem.14005

5. Fowler AA, Truwit JD, Hite RD, Morris PE, DeWilde C, Priday A et al. Effect of Vitamin C Infusion on Organ Failure and Biomarkers of Inflammation and Vascular Injury in Patients With Sepsis and Severe Acute Respiratory Failure: The CITRIS-ALI Randomized Clinical Trial. JAMA. 2019;322(13):1261-1270. doi: 10.1001/ jama.2019.11825 